\title{
Валентина Соболь
}

Uniwersytet Warszawski wsobol@uw.edu.pl

\section{Скорина про себе самого. Біографічний та автобіографічний контексти \\ (До 530-річчя від дня народження Францішка Скорини, 1486-1540 (1541-?) та до 500-річчя від виходу його Біблії)}

\section{Franciszek Skoryna o sobie samym. Biograficzne i autobiograficzne konteksty}

W artykule autorka stara się udowodnić, że Franciszka Skorynę można uważać za kontynuatora Włodzimierza Monomacha, który jako jeden z pierwszych napisał o sobie samym w Pouczeniu, adresowanym do dzieci. Tak jak metropolita kijowski Hilarion w Słowie o prawie i łasce Skoryna wielokrotnie podkreśla wyższość Nowego Testamentu nad Starym i pisze, że należenie do czasów Nowego Testamentu jest przywilejem, który nakłada obowiązki. Podkreśla, że posługuje się „słowiańskim językiem”, jest Słowianinem, Rusinem, Rutenem, pochodzi z narodu ruskiego. Pisał, że temu „przyrodzonemu narodowi” pragnie służyć "ku nauce”.

Słowa kluczowe: Franciszek Skoryna, druki Skoryny, Włodzimierz Monomach, metropolita kijowski Hilarion

Своїм завданням бачимо актуалізацію діапазону історико-літературних асоціацій, пов'язаних із феноменом Францішка Скорини одного із найважливіших діячів слов'янського i європейського 
відродження ${ }^{1}$. Поштовхом до постановки такої проблеми стали новочасні розвідки про Скорину, в яких увиразнено особистісні виміри долі ученого-сподвижника. Він вніс вклад до царини видавничої, перекладацької, літургійно-літературної, а також лікарсько-медичної. Доктор лікарських наук Скорина працював на стику двох великих традицій. Виріс і сформувався на східній традиції, але як учений, наголошує Олександр Наумов, Скорина є людиною Заходу, вченим, який водночас сміливо сягав до мудрості єврейських біблістів ${ }^{2}$. Марія Адамчик слушно додає, що поліглот і всебічно обдарований Скорина

przetrwat w pamięci jako ttumacz obdarzony wielka samoświadomościa teoretyczna $i$ niezwykłym wyczuciem lingwistycznym, czego dowodza dzieła i wypowiedzi Skorynicza o językach biblijnych, właściwościach języków wernakularnych i efektach cudzych (scil.) obcojęzycznych przekładów, sięgających ad fontes $i$ tworzacych sui generis serię translacyjna Pisma Świętego ${ }^{3}$.

Ще за його життя в латинській транслітератції був опублікований фрагмент руського перекладу із 23-го розділу Другої книги Самуеля. I здійснив це видатний італійський орієнталіст Тесео Амброджіо (Teseo Ambrogio (degli) Albonesi) ${ }^{4}$.

Наукове вивчення Скорини розпочалося в 1776 році в працях Й. Бакмейстера (Bacmeistera), П. А. Алєксєєва і Й. Стріттера (J. G. Stritter, 1783) та В. С. Сопікова (1813). У Польщі Скорині присвятили

${ }^{1}$ Висловлюю щиру вдячність колежанкам Галині Ковальчук та Наталі Лисенко (Київ) за допомогу у віднайденні потрібних матеріалів.

${ }^{2}$ A. Naumow, Rusin na szlakach renesansowej Europy, [w:] Franciszek Skoryna z Połocka-życie i pisma, wybór tekstów, przekład i oprac. M. Walczak-Mikołajczakowa, A. Naumow, red. A. Naumowa, M. Walczak-Mikołajczakowa, Gniezno 2007, s. 35.

${ }^{3}$ M. Adamczyk, Posłowie, [w:] Franciszek Skoryna z Połocka - zycie i pisma ..., s. 217 .

${ }^{4}$ Introductio in Chaldaicam linguam, syricam atque armenicam et decem alias linguas, Pavia 1539, s. 52. Дивись детальніше: A. Naumow, Rusin na szlakach renesansowej Europy, [w:] Franciszek Skoryna z Połocka-życie i pisma..., s. 16. 
свої праці польські вчені С. В. Лінде (S.B.Linde, 1815-1815; 1823), Й. С. Бандке (J. S.Bandkie, 1815, 1826), Й. Лелевель (J. Lelewel, 1823)5, M. Вішнєвський (M.Wiszniewski, 1851) та ін. Сьогодні існує досить розбудована спеціальна дисципліна - «скоринознавство».

Але звернімося до особистісних параметрів. Дата народження одного із найважливіших діячів слов'янства Францішка Скорини щоправда, із кваліфікацією «може, можливо» - окреслюється 6 березня 1486 року $^{6}$. Інші окреслення - поміж 1485 і 1490 роками. Він народився в Полоцьку, одному із головних міст польсько-литовської держави. Від 1105 року Полоцьк був садибою руського єпископату. На межі XV і XVI століть у місті проживало понад десять тисяч мешканців, переважно православного віросповідання. Як один із найважливіших духовних осередків християнства, Полоцьк оберігав культ святої княжни полоцької Єфросинії. У 1498 році Полоцьк здобув магдебурські права. Було зафундовано бернардинський монастир із костелом святого Францішка. Правдоподібно, саме тут Скорина навчився латини. Але спершу, за свідченням дослідників, Скорина навчався в школі при полоцькій кафедрі Божої Мудрості (Софії) з їі солідною бібліотекою. Згодом іï частково було перевезено до бібліотеки замойської ординації (Biblioteka Ordynarii Zamojskiej) та Національної бібілотеки (Biblioteka Narodowa w Warszawie).

Отож, витоки Скорини - Полоцьк. Але сформували його також Краків, Падуя, Прага і Вільно. Ці інтелектуальні центри навчили Скорину, як підкреслює О.Наумов, розуміти традицію „не як взірець до бездумного відтворення, а як динамічну спадщину, яка становить інтелектуальний виклик"7. Як висновує далі дослідник,

${ }^{5}$ Пізніше Лелевель опублікував гравюру з репродукціями празьких і віленських видань Скорини, див.: J. Lelewel, Album rytownika polskiego, Poznań 1854, tabl. XI.

${ }^{6}$ Franciszek Skoryna zPołocka - życie i pisma..., s. 9.

${ }^{7}$ Aleksander Naumow, Rusin na szlakach renesansowej Europy, [w:] Franciszek Skoryna z Połocka-życie i pisma..., s. 35. 
Скорина зі славного міста Полоцька немов би хотів своєю титанічною діяльністю довести усім людям європейських культурних погранич, що

tropienie, rozumienie, oswajanie i pokonywanie tego, co uwidacznia $i$ ukonkretnia różnice i podziały, jest najpewniejsza droga do wspótuczestnictwa $w$ kulturze, do współtworzenia jej niepowtarzalnych ponadnarodowych $i$ ponadkonfesyjnych, czy raczej - wielonarodowych $i$ wielokonfesyjnych odmian. To one stwarzaja szanse pokonywania nadmiaru odrębności, stanowia próby scalania odmiennych tradycji poprzez oswajanie cech, odbieranych w poszczególnych formacjach jako wyznaczniki przynależności. Takie działanie z reguły nie zadowala nikogo, nieraz, jak w jego wypadku, jest przyczyna osobistej klęski, ale, niezależnie od wszystkiego, nosi charakter bohaterskiego wyczynu i może, czy lepiej-powinno pobudzać do działania ${ }^{8}$.

2.

Францішек Скорина, як підраховано 994 рази називає власне прізвище Скорина, а 21 раз підкреслює, що він є Скорининим сином. А що особливо цікаво, в акровіршах обох авторських акафістів він подав ось яку форму: Скоринич Францискус. Щодо імені, то так само часто називає Францішек, а тільки раз - Франціско. Докладніше про це пише А. Журавський, зазначаючи, що ім’я Францішек вжито Скориною три рази в ранніх празьких виданнях 1517 року, один раз ця форма збереглася також і в передрукованій передмові до «Псалтиря» 1522 року. Але в усіх пізніших празьких виданнях і у віленському виданні «Апостола» Скорина вже не вживає цієї форми:

У передмові до 1-ї книги «Царства» один раз ужито форму називного відмінка Франиіско, в усіх останніх книгах його ім'я 64

\footnotetext{
${ }^{8}$ Ibidem, s. 36 .

${ }^{9}$ Ibidem, s. 14.
} 
рази зафіксовано у формі родового відмінка Франиіска, 150 разів у формі орудного відмінка Франціском ${ }^{10}$.

Особливо строкатим було вживання імені Скорини в 1950-60-х роках XX століття, коли в друку траплялися всі можливі варіанти: Франціск, Францішак, Георгій і Юрій ${ }^{11}$. I властиво це ми бачимо в працях Павла Попова, українського вченого, який не мав можливості доступу до архівних матеріалів. Натомість О. Яременко, автор статті від 1923 року, затитулував свою статтю Др. Францііск-Георгій Скорина, його життя та літературна і видавнича діяльність ${ }^{12}$.

Можемо вважати Скорину послідовником Володимира Мономаха, який одним із перших у літературному просторі Київської Русі залишив про себе самого чимало цінного й повчального у Повчанні дітям, своїм і нашим - усім нам. Скорина сповідував засаду: «Не роби іншому того, що тобі немиле». Треба відзначити, що давнє письменство - від Мономахового повчання дітям до філософських трактатів Григорія Сковороди - пройняте цим моральним імперативом, таким легким і водночас важким для виконання. Але сягнімо ще глибше до Повісті временних літ:

Wielki bowiem bywa pożytek z nauki książkowej; przez księgi bowiem napominani i pouczani jesteśmy o drodze do pokuty, madrość bowiem zyskujemy $i$ wstrzemięźliwość przez słowa ksiag, gdyż te sa rzekami napawającymi wszystek świat, sa źródłami mądrości; w księgach bowiem jest głębina niezmierzona, przez nie wszak w smutku pocieszani jesteśmy, one sa wędzidłami wstrzemięźliwości ${ }^{13}$.

${ }^{10}$ А. І. Журавскі, Імя і прозвішча Францыска Скарыны, [в:] Францзыск Скарына і яго час. Энцыклапедычны даведнік, Мінск 1988, с. 343; переклад українською - В. C.

11 Tamże, s.344.

${ }^{12}$ Ол. Яременко, Др Франціск-Георгій Скорина, його життя та літературна $i$ видавнича діяльність, „Літературно-науковий вісник” 1923, книга IX, за падолист, с. 253-259.

${ }^{13}$ Powieść minionych lat, przeł., oprac. F. Sielicki, Wrocław-Warszawa-Kraków 1999, s. 119. 
Порівняймо ці Несторові рядки із передмовою Скорини до книги Іова, де Скорина наголошує, що всякому чоловікові необхідно читати, бо це «ліки душевні, утіха усім сумним, а найбільше тим, які в біді або хворіють». А ще виразнішою $є$ подібність до цитованих вище рядків із Повісті временних літ - передмови Скорини до книги Соломонових притч:

Czytanie tych ksiag pożyteczne jest dla każdego człowieka: mądrego i nierozumnego, bogatego i biednego, młodego i starego, najwięcej zaś dla tych, którzy chca przestrzegać dobrych obyczajów i poznać mądrość i naukę, bowiem dtugie dni i lata życia i pokój będa do nich należaty; miłosierdzie i prawda ich nie opuszcza, jeśli pilnie postuchaja i będa przestrzegać przypowieści wyłożonych $w$ tych księgach, jak sam król Salomon niżej o tym mówi ${ }^{14}$.

Скорина і в празьких, і у віленських текстах багаторазово повторює, що він є християнином, але при цьому він не уточнює конфесії. Подібно як Іларіон Київський у Слові про Закон і Благодать, Францішек Скорина багаторазово підкреслює вищість Нового Завіту над Старим. Пише, що приналежність до часів Нового Завіту є привілеєм, який водночас накладає обов'язки. Бути християнином - не означає хвалитися хрещенням та віднайденим у результаті цього іменем, а це означає любити, вірити, мати надію, допомагати ближнім, виконувати заповіді, віддати всього себе в служінні Богові і людям. Писав, що в тілі всі ми діти Адама, а в дусі діти Ісуса Христа. I так як Єва постала з боку (з ребра) сплячого Адама, так само з боку Розіп'ятого народилася Церква, мати усіх християн. Народжуючись, отримуємо від Сви тіло і кров, а в сакраменті хрещення від Церкви отримуємо віру ласку і силу, а також усиновлення і примирення з Богом, оскільки Христос є Улюбленцем і Головою Церкви. Твердив сам про себе, що є слов'янином, а ще точніше - Русином, Рутеном, походить з народу руського і тому народові прагне служити,

${ }^{14}$ Franciszek Skoryna z Połocka-życie i pisma..., s. 97. 
послуговуючись слов'янською мовою. Майже в усіх колофонах називає себе доктором

в лекарских, лечебных на(в)уках, два рази називає «в лекарстве и в на(в)уках вызволеных» (BS JOZ i BS Jud) два рази - «в науках и лекарствах учитель» (BS Sdz i BS Est) ${ }^{15}$.

3.

Що є, з одного боку, дискусійним, з іншого, оприявнює ширший контекст, - це те, що Скорина вдається до етикету, притаманного давньоруському книжнику, коли сам себе називає простим чоловіком у контрасті до вчених докторів теології, що він пише згідно малого розуму свого.... Слушно зауважує з цього приводу О. Наумов:

Tę skonwencjonalizowana skromność warto odbierać $w$ biblijnym kontekście (Mt 11, 25 = Łk 10,21; 1 Kor 1,17-2,16), gdyż ma ona charakter apostolski. Uważa Skoryna, że jego dzieło to „małe książi”, którymi jakoś pragnie przystużyć się swojemu narodowi, ponieważ nie jest w stanie uczynić ,, rzeczy wielkich” $(B S K p t)^{16}$.

Порівняймо із твором Житіє і ходіння Данила, Руської землі ігумена, паломника кінця XI-початку XII століття:

Я, недостойний ігумен Руської землі Данило, найгіриий з усіх чениів, смиренний гріхами многими, недосконалий в усякому ділі благому, спонуканий думкою своєю і нетерпінням моїм, захотів побачити святий град Срусалим і землю обітовану ${ }^{17}$.

Скорину, vir doctus, русина і водночас громадянина Європи, Наумов називає правдивий homo viator, який увійшов до історії як ти-

${ }^{15}$ A. Naumow, Rusin na szlakach renesansowej Europy, [w:] Franciszek Skoryna z Połocka-życie i pisma..., s. 16.

${ }^{16}$ Ibidem, s. 16.

${ }^{17}$ Українська література XI-XVIII cm. Хрестоматія з коментарями, упоряд. Є. А. Карпіловська, Л. О. Тарновецька, Чернівці 1997, с. 47. 
тан праці і як творець Біблї руською мовою, яка вперше побачила світ у 1517 році.

Хоча сам про себе Скорина сказав чимало, але його життя в роках і датах має кілька білих плям. Перша: немає жодних документів про те, чим займався між 14 грудня 1506 і 5 листопада 1512 року, коли властиво відбулося зібрання у справі допуску до докторського екзамена в Падуї. Натомість достеменно знаємо, що на початку осені 1504 року юний Скорина з Полоцька приїхав на студії до Краківської Академії. 19 жовтня розпочав зимовий семестр. 3 ним разом розпочало навчання 150 студентів 3 різних куточків світу, а $з$ Польщі - $141^{18}$. В Академії мав нагоду слухати виклади видатних учених Яна Глоговчика, Марціна Бема з Олькуша, Яна зі Стобниці і інших.

14 грудня 1506 - знаменний день у долі 60 студентів (3-посеред них Скорини) Краківської Академії. 60 студентів завершило дворічну програму і здобуло бакалаврат. Саме 14 грудня 1506 року 15 колег Скорини отримали ступінь бакалавра, але ім'я тільки одного з-поміж тих п’ятнадцяти - Андрія з Пакосці (Andrzej z Pakości) увійшло до історичної пам'яті. Він був залишений в Академії, у 1510 році викладав етику та економію Аристостеля, потім був в Гнєзно прокуратором (про це є згадка в університетській Księdze promocji - Statuta nec non liber promotionum philosophorum ordinis in Universitate studiorum Iagellonica, ab anno 1402 ad anum 1849 (ed. J. Muczkowski, Cracoviae 1849, p. 144), оригінал якої зберігається в Ягеллонській Бібліотеці, sygn. 263, k.62).

Правдоподібно, саме в Кракові Скорина зіткнувся зі свіжою традицією перерваного друкарства підприємливого німецького діяча Швайпольта Фіоля. Безперечно, навіть після 12-14 років живою була пам'ять про те, як у 1490-1493 роках у Кракові в друкарні Швайпольта Фіоля було видрукувано чотири літургійні

${ }^{18}$ A. Naumow, Rusin na szlakach renesansowej Europy, [w:] Franciszek Skoryna z Połocka-życie i pisma..., s. 10. 
церковнослов'янські книги, що стало підвалиною кириличного друкарства в світі.

Друга невідома - де саме Скорина здобув магістеріум, де студіював обов'язкові перед докторатом три роки науки та рік медичної практики. Гіпотетично називають Краків, Ерфурт або ж Росток. Вiдомо, що Скорині вдалося використати перерву у військових діях, коли Падуя стала безпечною, і хоча в Падуанському університеті не відбувалися дидактичні заняття, зате провадилися докторські промоції. Це відбувалося в три етапи. Спершу докторант просив про «ласку», аби приступити до екзамену, наступно відбувався пробний іспит (tentativum) і врешті властивий іспит (privatum examen). У 321 томі 3 історичного архіву Падуанського Університету збереглися протоколи всіх трьох етапів. Перший етап відбувся 5 листопада в костелі святого Урбана, коли «дуже вчений і бідний юнак» Скорина, який прибув 3 дуже далеких країв, «відлеглих щонайменше на чотири тисячі миль», став перед Колегіумом, здобув високу оцінку і був допущений до другого етапу. Другий етап відбувся наступного дня в тому ж самому місці з позитивним висновком. Три дні пізніше, 9 листопада 1512 року, в єпископському палаці Скорина склав властивий іспит і отримав інсигнію доктора медичних наук. Білоруський науковець У. Калеснік в енциклопедичній статті «Франиыск Скарына і яго час» пише, що це була знаменна подія і в житті Скорини, і в історії культури Білорусі - купецький син $з$ Полоцька довів, що «знання і покликання варті більше, аніж аристократичне походження» ${ }^{19}$. О. Наумов ${ }^{20}$ установив, що в Краківській Академії перший такий акт - докторат у царині медицини - відбувся аж у 1527 році.

Третя невідома в біографії - ще нікому не вдалося встановити, що робив Скорина далі до 1517 року. Відомо тільки, що відвідав

${ }^{19}$ У. А. Калеснік, Франщуыск Скарына і яго час, [в:] Франц̧ыск Скарына і яго час. Эниыклапедычны даведнік, Мінск 1988, с. 218.

${ }^{20}$ A. Naumow, Rusin na szlakach renesansowej Europy [w:] Franciszek Skoryna z Połocka-życie i pisma..., s. 11 . 
Венецію - один із найважливіших осередків європейського друкарства (в тому числі і слов'янського, грецького і гебрейського). У Венеції вже тоді діяло близько 150 друкарень. Так, польські гуманісти підтримували контакт зі славною друкарнею Альда Манузіа (1449-1515), а в друкарні його тестя Андреї Торресані в 1493 році хорвати видрукували глаголичний молитовник.

Таким чином, моделювання рецептивних ситуацій - як саме (що є цілком імовірним) - твори старокиївського письменства відлунили в доробку Скорини - такий підхід не заповнює білих плям, але наближає до розуміння ментальності творця тієї доби. Адже його спадщина становить інтелектуальний виклик нашій добі.

\section{Література}

Adamczyk M., Posłowie, [w:] Franciszek Skoryna z Polocka-życie i pisma, wybór tekstów, przeł. i oprac. M. Walczak-Mikołajczakowa, A. Naumow, red. A. Naumow, M. Walczak-Mikołajczakowa, Gniezno 2007, s. 216-218.

Naumow A., Rusin na szlakach renesansowej Europy, [w:] Franciszek Skoryna z Połocka - życie i pisma, wybór tekstów, przeł. i oprac. M. Walczak-Mikołajczakowa, A. Naumow, red. A. Naumow, M. Walczak-Mikołajczakowa, Gniezno 2007, s. 9-36.

Powieść minionych lat, przeł., oprac. F. Sielicki, Wrocław-Warszawa-Kraków 1999.

Анічэнка У. В., Скарынінская, спадчына у рукапісах яго паслядоунікау на Украіне, [в:] Францыск Скарына і яго час: Энџыклапедычны даведнік, Мінск 1988, с. 499-500.

Журавскі А. І., Імя і прозвішча Францыска Скарыны, [в:] Францыск Скарына і яго час. Энцыклапедычны даведнік, Мінск 1988, с. 343-344.

Ісаєвич Я., Скорина і початок книгодрукування на Украйні, [в:] Францыск Скарына і яго час: Энцыклапедычны даведнік, Мінск 1988, с. 493-494.

Історія української літератури, е. 2: Давня література (друга половина XVI-XVIII ст.), ред. В. Сулима, М. Сулима, Київ 2014.

Калеснік У. А., Францыск Скарына і яго час, [в:] Францыск Скарына $і$ яго час. Эниылклапедычны даведнік, Мінск 1988, с. 218-219.

Ковальчук Г., Вклад члена-корреспондента АН УССР П.Н.Попова в изучение книжной культуры [в:] Берковские чтения 2015. Книжная культура в онтексте международных контактов: Материалы третьей Международ- 
ной научной конференциив Минске 26-27 мая 2015 года, Минск-Москва 2015, c. 188-193.

Ковальчук Г., Изучение и популяризаџия наследия Франииска Скорины украинским ученым П.Н. Поповым [в:] Матэрыялы ХІ Міжнародных кнігазнавчых чытання в Мінску 16-17 красавіка 2015 г., „Кніжная культура Беларусі XI- пачатку XX ст.”, складальнікі: Г. У. Кірєева, Т. А. Сапега, А. А. Суша, Мінск 2015, с. 18-22.

Лист Сергія Маслова до Юрія Меженка від 27 вересня 1932 року, Інститут рукописів Національної Бібліотеки України ім. Вернадського, фонд 33 (архів Сергія Маслова), од. зб. 4893.

Українська література XI-XVIII cm. Хрестоматія з коментарями, упоряд. Є. А. Карпіловська, Л. О. Тарновецька, Чернівці 1997.

Яременко Ол., Др Франиіск-Георгій Скорина, його життя та літературна i видавнича діяльність, „Літературно-науковий вісник” 1923, книга IX, за падолист, с. 253-259.

\section{Francysk Skoryna about himself}

In the article, the author demonstrates that Francysk Skoryna can be considered a follower of Vladimir Monomakh. The latter, as one of the first in the culture of Kievan Rus', in his Instruction (also known as The Testament) to his own children, refers to his own life and deeds. Skaryna often uses a topos of modesty calling himself "a simple man"; 94 times he mentions his own surname, 21 times he calls himself "a son". He frequently refers to himself as Franciszek and just once as Francysk. In his works of Prague and Vilnius period he calls himself a Christian, however he does not specify a denomination. Just like Hilarion of Kiev in his Sermon on Law and Grace, Skoryna proclaims the primacy of the New over the Old Testament. He says that living in the period of the New Testament is a priviledge that implies duties. He also states that he is Ruthenian, comes from people, simple folk and wants to serve it.

Key w o rd s: Francysk Skaryna, Skaryna's publications, Vladimir Monomakh, Hilarion of Kiev 